\title{
"El Infierno": A Critical Discourse Analysis of Narco Culture in a Mexican Film
}

\author{
Cinthya Patricia Ronquillo Montes \\ University of Guanajuato, MEXICO \\ Division of Social Sciences and Humanities
}

Received: 10 June 2020 - Accepted: 9 October 2020 - Published Online: 21 November 2020

\begin{abstract}
The portrayal of narco culture in media has increased in recent years as a result of the War of Drugs in Latin America. This paper, based on critical discourse theory and Halliday's (1978) Systemic Functional Linguistics (SFL), sheds light on the social and cultural impact of discourse found in a scene of the Mexican film "El Infierno" directed by Luis Estrada in 2010. Through the ideational and interpersonal processes, the dialogues of two speakers are analyzed. Additionally, the social impact of the discourse portrayed in the scene is discussed through Fairclough's (1992) social theory of discourse. Findings suggest that social reality is reflected in the film through discourse as a means to develop critical thinking and reflection in the audience.
\end{abstract}

Keywords: critical discourse analysis, ideational function, interpersonal function, narco culture, film.

\section{Introduction}

This paper presents a critical discourse analysis (CDA). This analysis aims to (1) determine how accurate a scene from the film "El Infierno" reflects the reality of the current Mexican society and (2) shed light on the social and cultural impact of the speech represented in the movie scene. I open the discussion by providing a theoretical background of the narco culture in media and a brief description of the film. Then, I will explain the ideational and interpersonal function proposed by M. A. K. Halliday employed for this analysis. This will be followed by the results of the analysis and their interpretation. Finally, the social impact of the discourse will be presented through the lenses of Fairclough's (2010) sociocultural perspective.

\section{Theoretical framework}

Before discussing the methodological procedures implemented in this analysis, it is crucial to understand how the concept of "narco" emerged, and how it has become part of the media and culture of the Mexican society. To provide this understanding, I will first address the key aspects that shape narco discourse, followed by a description of the movie.

(C) Authors. Terms and conditions of Creative Commons Attribution 4.0 International (CC BY 4.0) apply. Correspondence: Cinthya Patricia Ronquillo Montes (MA student), University of Guanajuato, Division of Social Sciences and Humanities, Guanajuato, MEXICO. E-mail: cp.ronquillo.m@gmail.com. 
- Narco culture is present in the film "El Infierno" (2010) and was employed by the director Luis Estrada as a call for the viewer towards the current situation of narco and its repercussion in the Mexican society.

- By means of Halliday's (1978) systemic functional linguistics, it was found that the discourse portrayed in the film scene comprises linguistic features employed in everyday conversation that reflect naturality of the speech community and, thus, social reality.

- Through CDA, it became evident that the director's intention was not that of hiding Mexico's reality but rather to unveil and shed light on the underlying components of the war against drug trafficking.

\subsection{Narco culture in media}

The concept of narco emerged during the 1970s in Mexico. It is rooted in the drug trafficking cartels that initiated during that time. Haidar and Herrera (2018) claim that the concept of narco culture is reflected in media through songs (narcorridos), films, and TV series, narco-literature (Michael, 2013; Fuentes Kraffczyk, 2019) and even in narco-advertisement (Campbell, 2014). In line with this, Cabañas (2014) states that:

The effects of the War on Drugs have become an everyday topic of conversation and study, appearing in newspapers, academic publications, and cultural products such as literature, film, music, telenovelas, blogs, online videos, performances and popular art in Latin America. A new vocabulary to describe these phenomena now punctuates journalistic discourse: narcoculture, narconovelas, narcodemocracies, narcoaesthetics, and narco religion. Cultural artifacts reflect how narcotrafficking and the War on Drugs affect individuals and their communities. (p. 4)

From this quote, the interplay between drug trafficking, society, and discourse is evident. Moreover, Cabañas (2014) further pinpoints that despite the so-called war on drugs began in 1971 it continues to shape current everyday discourse. Marez (2004) addresses this influence and argues that:

mass media representation of drug traffic and enforcement have helped to generate powerful ideas about state power, foreign policy, and transnational capitalism. And drug-war literature, music, television and films have become privileged cultural forms for reflecting upon larger political-economic power relations in the Americas. (p. 3)

From this, we can infer that media has the power not only to shed light on polemic aspects in society but also to reflect and promote power and ideologies. The controversy this generates in society has produced significant economic profits that have largely increased the popularity of narcoculture in media. For example, in the Mexican context, as Gómez Mayorga and Garcia Rangel (2013) observe, "narcoculture has generated a whole emporium of violence with millionaire annual earnings" (p. 3).

In this regard, Sibila and Weiss (2014) indicate that narco-cinema has become a growing industry that alludes to the narco culture that has uncontestably escalated through modern society. The authors draw special attention to the film "El Infierno" and describe it as "an epic satire that examined the politics surrounding the drug trade" (p. 3). A more detailed description of the film is provided in the following section.

\subsection{Film description}

The Mexican drama film "El Infierno" was written, produced and directed by Luis Estrada and was released on 3 September 2010. The C-rating film narrates the problematic of drug 
trafficking and organized crime in Mexico and takes place during the celebrations of the 200 $^{\text {th }}$ anniversary of Mexico's Independence. The protagonist is Benjamin García, better known throughout the film as "El Benny". The Mexican actor Damián Alcazar, who has also participated in other controversial movies that target Mexican social reality, stars him. El Benny is deported from the United States after 20 years of working as an illegal. He returns to his hometown "San Miguel Narcangel" (name given by the combination of the words narco and archangel) only to face a bleak picture of poverty and violence caused by the local business: drug trafficking. The plot presents the story and the reasons that influenced El Benny's decision to join the drug cartel, and the consequences this decision had not only for him but also for those who surrounded him.

In this paper, the dialogues from the scene that takes place from minute 23:25 to 25:55 are analyzed under CDA. The two main speakers are Cochiloco, interpreted by the actor Joaquin Cosio, and El Benny. In this scene, both speakers have a conversation after twenty years of not seeing each other and discuss what has happened during this time. The setting of the scene portrays a traditional Mexican cantina, as Image 1 depicts.

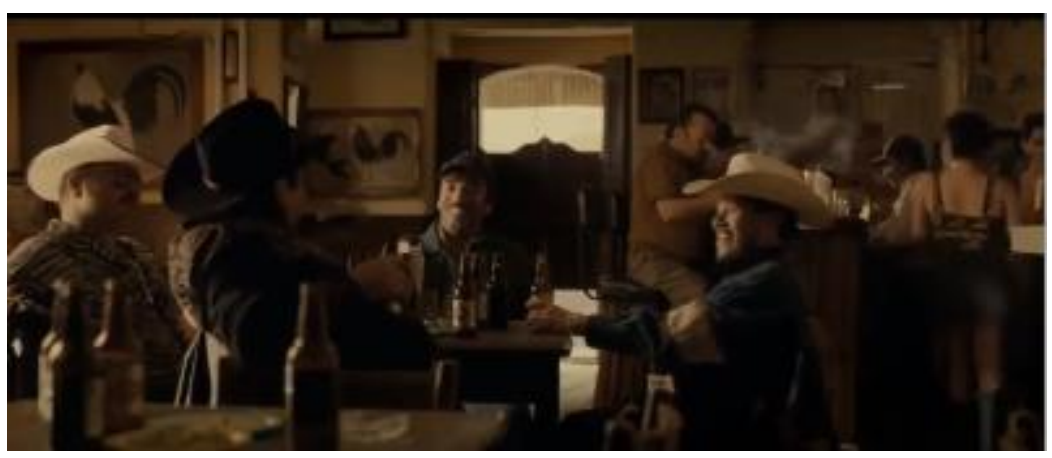

Image 1. Scene setting. Copyright (C) 2010, Bandidos Film

The setting and the dialogues presented in the scene coincide with each other and resemble an ordinary conversation between two friends that could take place practically in every place of Mexico. A more in-depth analysis of other elements that help construct Mexican reality are further discussed in section five.

\section{Methodology}

This section presents the methodology employed to carry out the analysis and the framework through which the dialogues of the film scene were analyzed.

\subsection{Critical discourse analysis}

As previously stated, this paper sets out to examine how social reality is portrayed in the film scene "El Infierno," as well as the way the speech employed culturally impacts society. To do so, CDA was implemented as the research methodology. CDA, as described by Blommaert and Bulcaen (2000), is a "school of discourse analysis that concerns itself with relations of power and inequality in language" (p. 1). Haratyan (2011) argues that "discourse analysis is concerned with the lexico-grammatical analysis of the language in the social, physical, cognitive, cultural, interpersonal and situational context" (p. 1). Blommaert and Bulcaen (2000) further pinpoint the works of Norman Fairclough, Ruth Wodak, and Teun van Dijk as the precursors of CDA in the late 1980s. According to Wodak (1995), CDA's aim is the analysis of "opaque as well as transparent structural relationships of dominance, discrimination, power, and control as manifested in language” (p. 204). Additionally, Wodak (1997) indicates that through the lenses of CDA, oral and written discourse is perceived as "a form of social practice" (p. 173). Due to its foundation on social 
practice, discourse has a significant influence on society and vice versa. This means that both of these elements inform, construct, and shape each other (Wodak, 1997). Being the latter, the focus of the present analysis as a means to comprehend the extent to which the scene's dialogue reflects Mexican society and the impact it has on society.

\subsection{Halliday's (1978) systemic functional linguistics}

In order to uncover the underlying components of the speech in the dialogues, the discourse was analyzed through the scope of Halliday's (1978) systemic functional linguistics (SFL). Haratyan (2011) explains SFL "is concerned with how the speakers generate utterances and texts to convey their intended meanings through the generalized metafunctions that relate language to the outside world where interactants and their social roles matter" (p. 260). This framework includes three levels of analysis: ideational, interpersonal, and textual. Through the ideational function, speakers can express the way they perceive the world and how they experience and react to it. This function comprises six communicative processes: (1) material, (2) relational, (3) mental, (4) verbal, (5) behavioral, and (6) existential. Romo Linares (2018) describes these processes as follows:

The material process indicates an action with a direct object while the mental is only used for perceptions and reactions. Verbal processes are used to exchange information or describe, similarly the relational process is used to identify or attribute characteristics. We also express physiological or mental behaviors through the behavioral process. Lastly, we use the existential process to present something that exist or happens. (p. 50)

Concerning the interpersonal function, Halliday (1978) claims this language function relates to the "comments, attitudes, and evaluations in relation to the particular communication roles" (p. 333) individual speakers express. Finally, the textual functions deals with "the internal organization and communicative nature of a text" (O'Hallaran, 2006: 36). The three levels Halliday propounds work as a system in which although every level is analyzed individually, the perspective of the complete utterance and dialogue is the central criterion. For the purposes of this study, the ideational and interpersonal levels were conducted. The results obtained from these functions are provided in the following section.

\section{Analysis and results}

This section sets out to present the emergent results of Halliday's (1978) SLF framework and their interpretation. The analysis is divided into two main sections. The first part is concerned with the ideational function analysis (transitivity) and the second part with the interpersonal function. Within the second, the modality analysis of verb tenses and personal pronouns are included.

\subsection{Ideational function}

According to Halliday (1971), "it is through this function that the speaker or writer embodies in language his experience of the phenomena of the real world; and this includes his experience of the internal world of his own consciousness: his reactions, cognitions, and perceptions, and also his linguistic acts of speaking and understanding (p. 332). Thus, through the ideational function, the hearer or audience can comprehend the way the speaker perceives the world. These ideas are transmitted through the transitivity system, which Haratyan (2011) describes as "a rich analytic tool utilized in CDA, dealing with "who or what does what to whom or what?” (p. 261). In this function, the dialogue from the scene script was classified into the six 
processes the level comprises. The utterances from each speaker were analyzed individually to compare and contrast the differences in their speech. Table 1 illustrates the results, and Table 2 shows examples of the six processes from each speaker.

Table 1. Transitivity analysis

\begin{tabular}{|l|c|c|c|c|}
\hline \multirow{2}{*}{ Process } & \multicolumn{2}{|l|}{ Total of words: 271 } & \multicolumn{2}{l|}{ Total of words: 88 } \\
\cline { 2 - 5 } & \multicolumn{2}{|l}{ Speaker 1: "El Cochiloco" } & \multicolumn{2}{c|}{ Speaker 2: "El Benny" } \\
\cline { 2 - 5 } & Count & $\%$ & Count & $\%$ \\
\hline Material & 19 & $7 \%$ & 8 & $9 \%$ \\
\hline Relational & 6 & $2.2 \%$ & 0 & - \\
\hline Mental & 3 & $1.1 \%$ & 2 & $2.2 \%$ \\
\hline Verbal & 5 & $1.8 \%$ & 1 & $1.1 \%$ \\
\hline Behavioral & 14 & $5.1 \%$ & 1 & $1.1 \%$ \\
\hline Existential & 6 & $2.2 \%$ & 1 & $1.1 \%$ \\
\hline
\end{tabular}

Table 2. Examples of the processes

\begin{tabular}{|c|c|c|}
\hline Process & Cochiloco's discourse & El Benny's discourse \\
\hline Material & $\begin{array}{c}\text { Go, work, kill, come, celebrate, } \\
\text { toast,come back, do }\end{array}$ & $\begin{array}{l}\text { Defend, make, listen, happen, } \\
\text { know, put, go back }\end{array}$ \\
\hline Relational & Know, Was, present, is & - \\
\hline Mental & Being sad, get into, & See, believe \\
\hline Verbal & Say, mention, let's go & tell \\
\hline Behavioral & Leave, try, know, need & Wanted \\
\hline Existential & Forms of be, there is & Form of be \\
\hline
\end{tabular}

The first outstanding finding was the differences in the number of utterances of each speaker. Cochiloco spoke 271 words, whereas Benny had a more passive role in the conversation since he only employed 88 words. This seems to indicate that the speaker who had a larger domain of the conversation was Cochiloco, primarily because Benny focused on making questions, which were later answered by Cochiloco. This appears logical since Benny was asking, and Cochiloco was the primary source of input. This aligns with Wang's (2010) statement, which explains that the purpose of the ideational function "is to convey new information, to communicate content that is unknown to the hearer. It reflects the events and experience in both objective and subjective worlds (p. 255). In this case, Cochiloco's knowledge derives from his closeness not only to the town "San Miguel Narcángel" but also to the local business of drug trafficking.

Concerning the six processes, the data reveals that the most implemented process by both speakers is the material. This indicates that Cochiloco and Benny's speech in this scene focuses on visible action verbs. For example, Cochiloco employs the material process to tell Benny actions that occurred before to other people both know, how his brother was killed and how Cochiloco avenged this death. Additionally, Cochiloco expresses through the material process aspects in the present tense through words such as celebrate and toast. This seems to suggest that the speaker considers the present as a time in which one should not worry about the past nor the future, but simply enjoy the present. Lastly, Cochiloco also uses this process to advise Benny not to go back to the US and work in Mexico in the drug trafficking business. On the other hand, Benny, through the material process, presents his doubts to Cochiloco as well as the intention he had of having an English school, which vanished once he observed the local situation.

The second most used process by Cochiloco is behavioral. He expresses actions triggered by behaviors to indicate what the other speakers should do, as a declarative statement. Also, he employs the behavioral process to refer to the needs that Benny could have, which could be solved by being a member of the drug trafficking business. Benny also employs this process but in a low percentage (1.1\%) to refer to the above-mentioned desire to set up a language school. 
In regards to the existential process, Cochiloco employs it six times (2.2\%), whereas Benny only once (1.1\%). Through this process, Cochiloco addresses (a) how immigration and drug trafficking are the only two choices for people in San Miguel Narcángel, (b) the constant struggle to defend the "plaza", (c) drug trafficking as a medium to earn money in Mexico, and (d) his invitation to Benny to join him in the drug cartel. With this, Benny does not only acknowledge the real situation this town faces but the reasons why drug trafficking has become the only way to survive without having to migrate to the US. Nevertheless, in this scene, Benny implements the existential process to state that "No mi Cochi, pues muchas gracias pero pues el business no es pa'mi" / "No my Cochi, thank you very much, but the business is not for me." Although it is used only once, it reflects Benny's firm position at that time towards becoming part of the drug cartel by stating drug trafficking is not for him.

Subsequently, only Cochiloco employs the relational process (2.2\%). This use serves three main purposes: (1) establish how long-ago Benny and Cochiloco know each other, and (2) describe Benny's brother "El Diablo". First, Cochiloco expresses: Pues aquí el Benny y yo nos conocemos desde chavalillos, ¿veda cabrón / Well, Benny and I know each other since kids, right cabron. Through this utterance, Cochiloco explains that his relationship with Benny dates back to their childhood. Another interesting finding here is how this statement represents a breakdown in the phatic function of language (see Jakobson, 1960). This function is concerned with opening the channel of communication and is generally portrayed in conversation with strangers. Nevertheless, at the beginning of the dialogue, no phatic statement was employed, suggesting the close relationship between the speakers. Moreover, the phatic function breakdown additionally appears to indicate a characteristic of the closed narco society. This trait is that unless you are part of the drug cartel or a friend of someone who is a member, you may be informed about the inner aspects the business entails.

Second, utilizing the relational process, Cochiloco expresses an attribute of El Diablo (Benny's brother), who gained his nickname due to his actions in the drug cartel. Cochiloco describes him as: "era un chingón el cabrón", "era un chingón" and "Diablo que era un vato de ley". Through these descriptions, not only Benny but also the audience of the movie can infer how the members of drug cartels are perceived in this society. The word "chingón" is a Mexican slang that refers to "a masculine sense of power" (Castellanos, 2011: 269). By describing El Diablo as "chingón", Cochiloco reflects an attribute of narcos that remains even after their death and is continuously portrayed in media.

Finally, in Benny's speech, the mental process was expressed (2.2\%) through verbs such as see and believe, as in the following utterance: "Pos quería poner una escuela de inglés, pero pues como veo que están las cosas yo creo que mejor me retacho para el otro lado" / "Well I wanted to set up an English school, but now how I see things are I believe I better go back to the US". In this quote, the theme of how immigrants perceive their future when they return to Mexico is evident. Benny in this case due to the English he learned while living in the US for twenty years aimed to set up a language school, nevertheless, once he noticed it was not feasible he determined it would be a good choice to simply go back to the US, rather than joining the cartel.

The remaining processes did not have a significant percentage of usage and thus the discussion on transitivity analysis concludes here. In the following section, the interpersonal function is addressed.

\subsection{Interpersonal function}

This section sets out to discuss the interpersonal function. According to Zhuanglin (1988), "the interpersonal function embodies all uses of language to express social and personal relations” (p. 313). Sharififar and Rahimi (2015) further add that this function entails three areas: 
(1) speaker/writer persona, (2) social distance, and (3) relative social status" (p. 344). It is within this function that the relationship between the speakers and how this interplay shapes their discourse choices become apparent. Moreover, the interpersonal function can be expressed through modality and mood. Modality "shows what role the speaker selects in the speech situation and what role he assigns to the addressee" (Wang, 2010: 255). Mood can help to "express the speaker's judgement toward the topic...and to show the social role relationship, scale of formality and power relationships" (Wang, 2010: 256). In this paper, modality would be analyzed through the use of verb tenses and personal pronouns in the discourse. Each of them is discussed as follows.

\subsubsection{Verb tenses}

Table 3. Verb tenses modality

\begin{tabular}{|l|c|}
\hline Verb tense & Count \\
\hline Past & 21 \\
\hline Present & 33 \\
\hline Future & 1 \\
\hline
\end{tabular}

Table 3 shows that the present tense was the one employed the most in the dialogue. This seems to be in alignment with the purpose of the conversation, which is to inform Benny about the current state of the town. He had left twenty years ago, so, during this conversation, Cochiloco informs him about what is currently happening. The second most significant was the past tense. This tense functions as an indicator of the strong relationship between the speakers, since their friendship begun in their childhood. Also, through the past tense, Cochiloco informs Benny of what happened during the time he was not in the town, drawing particular emphasis on how Benny's brother died and how being part of the narco cartel influenced his death being shot by a rival cartel. Moreover, the topic of narco is introduced to the conversation in the following lines:

El Benny: "Nos hicimos amigos porque me defendía de un cabrón grandote, el orejas, ¿qué se hizo de ese hombre?"

El Cochiloco: "Pues lo que todos, los que no se fueron pal' otro lado como usted cabrón se metieron al bisne y se los cargó la chingada."

This excerpt reflects, as previously stated, how the citizens of the town only had two options, either (1) to migrate to the US or (2) to join the "bisne" (business) and thus, eventually die. There was no need to state explicitly that the bisnes refers to narco because perhaps Benny already perceived this as soon as he arrived in town. In addition, by stating "lo que todos" / "what everyone does" Cochiloco informs Benny that this is a concurrent situation in San Miguel Narcángel.

Regarding the future tense, the only time it was employed was when Cochiloco questioned Benny about his plans in town after coming back from the US. In general, through the verb tenses modality analysis, an everyday conversation was reflected. If you have not seen someone for a while, people are likely to provide you a summary using the past tense. Thus, no unexpected results emerged from this analysis. Nevertheless, it could also be inferred that the business of drug trafficking is not recent since it has been occurring for a while. Having discussed the verb tenses modality, I now turn to the analysis of personal pronouns. 


\subsubsection{Personal pronouns}

As previously argued, social distance in discourse can be determined through the interpersonal function. Coffin (2006) explains that social distance deals with "how close the speakers are, e.g. how the use of nicknames shows the degree to which they are intimate (pp. 2223). This distance can be explored through the use speakers have of the personal pronouns, as table 4 shows.

Table 4. Personal pronouns modality

\begin{tabular}{|c|c|c|c|}
\hline \multicolumn{2}{|c|}{ Personal pronouns } & Count in & Count in \\
\hline \multirow[t]{2}{*}{ First person } & $\mathrm{I}$ & 1 & 3 \\
\hline & $\mathrm{We}$ & 9 & 2 \\
\hline Second person & You & 9 & 1 \\
\hline \multirow[t]{4}{*}{ Third person } & $\mathrm{He}$ & 4 & 1 \\
\hline & She & 1 & $\mathrm{O}$ \\
\hline & It & O & O \\
\hline & They & 3 & $\mathrm{O}$ \\
\hline
\end{tabular}

The analysis uncovers the close relationship between the speakers in the predominance of the first person singular and plural pronouns I and we. In the conversation, Cochiloco employs the personal pronoun "we" nine times to express a sense of unity with Benny and members of the cartel. This is portrayed in the following examples:

"Pues aquí el Benny y yo nos conocemos desde chavalillos, ¿veda cabrón?”

"Su carnal trabajaba para los Reyes como todos nosotros."

"No sea pendejo Benny, a que chingados se regresa con los gringos que nomás nos tratan con la punta del pie cabrón."

In the last excerpt, the perception Cochiloco has towards Americans is also depicted. He advises Benny not to go back to the US do to the mistreating we (either only him and Benny or perhaps all Mexicans) receive from people from the US.

An interesting finding related to the use of the pronoun you is that in the conversation, it was used as "usted." In Spanish, de decision between to use you as tú or usted lies on power, meaning that people in a lower position tend to address those in a higher one with "usted" as a sign of respect or obedience. However, in this case, no issues of power were present since Benny was not an employee of Cochiloco. This seems to imply that both speakers use the pronoun usted as a symbol of respect grounded on friendship.

In relation to the above, the use of nicknames as a means to diminish social distance, both speakers refer to each other employing the first person possessive "mi" / "my". This aligns with Sharififar and Rahimi (2015) argument, which mentions that a "speaker uses language to provide a relationship between himself and hearer" (p. 344). It appears that such closeness did not take place during the conversation but in the speakers' childhood, and despite the pass of time, it prevails.

Finally, Cochiloco used the pronoun they to refer to the people who killed Benny's brother and to those who have died for being part of the drug trafficking business. By doing so, Cochiloco is detaching himself from them.

To conclude the analysis results section, it is essential to highlight that by combining the results of the ideational and the interpersonal function it is evident that the discourse presented by the speakers reflect a natural everyday conversation. This seems to suggest that the dialogue coincides with the communities' speech, and thus, it resembles society's reality. Through this CDA analysis, it has been proven that the script under analysis accurately reflects the reality 
of Mexican society in 2010. I will now turn to discuss the social impact of the discourse portrayed in the film in the following section.

\section{Social impact}

As previously mentioned, the interplay between discourse and social practice is the primary concern of CDA since one largely influences the other. According to Fairclough (2001), the process CDA follows is (1) "description of the text, (2) interpretation of the relationship between text and interaction, and explanation of the relationship between interaction and social context (pp. 21-22). It is within this process that the linguistic choices of the speaker become apparent and may be potentially understood not in isolation but contextualized. In line with this, Orpin (2005) argues that language is "firmly rooted in its sociolinguistic context" (p. 37). Thus, it is of paramount importance to view discourse from a sociocultural perspective, and here is where the implementation of Fairclough's approach is appropriate and valuable.

Fairclough's (1992) social theory of discourse "provides a methodological blueprint for critical discourse analysis in practice" (Blommaert \& Bulcaen, 2000: 448). The author's framework comprises the dimensions: discourse as text, discourse as discursive practice, and discourse as a social practice. For the purposes of this analysis, the second dimension is the one carried out. Blommart and Bulcaen (2000) indicate that this dimension considers "discourse as something that is produced, circulated, distributed and consumed in society" (p. 448). Through this description, the dynamics and constituents of discourse in social settings are noticeable. In this regard, Chouliaraki and Fairclough (1994) claim that:

It is an important characteristic of the economic, social and cultural changes of late modernity that they exist as discourses as well as processes that are taking place outside discourse, and that the processes that are taking place outside discourse are substantively shaped by these discourses. (p. 4)

In other words, in order to gain a broader understanding of discourse, it is not sufficient to look at the internal constituents but also those elements that coexist outside of discourse. Taking this into the CDA of the scene from the film "El Infierno", it is crucial to determine and discuss the external aspects that help construct the meaning and the comprehension of its discourse. In what follows the questions of who produced the film, why was it produced, to whom and for what are addressed.

The Mexican writer, director, and producer of the film "El Infierno" is Luis Estrada. The movie was created as a response to the call made by Instituto Mexicano de Cinematografía (IMCINE) for the 200th anniversary of Mexico's independence. According to Gómez Mayorga and Garcia Rangel (2013), the director Luis Estrada saw "the excuse of the official commemoration as an opportunity to display the harsh situations we live in the country" (p. 1). These authors further argue that:

the movie questions several violent actions that are so pervasive in our daily life that suggest thinking them as indicators of identity (p. 1) By producing the film, Luis Estrada completes his well-known film trilogy: "La ley de Herodes" (1999), "Un Mundo Maravilloso" (2006) and "El Infierno" (2010). Through this trilogy of satire films, this director approaches "diverse situations of political and social corruption, economic crisis, crime and delinquency present in the country since decades ago. (Gómez Mayorga \& García Rangel, 2013: 2).

Haddu (2016) describes the film "El Infierno" as the most direct and devastating political criticism that has ever been seen in Mexican cinema" (p. 630). The author further states that this film "was the first movie to focus on the drug war" (p. 630) that took place in the country in 2010 by making "direct references to present and past political figures in Mexico" (p. 630). 
Gómez Mayorga and García Rangel (2013) indicate "the film shows explicit visual, verbal, auditory forms, dramatic and intertextual of violent acts linked to intrigue, corruption, robberies, death, murders, vandalism, unemployment, among other devastating circumstances” (p. 2). Fernández Poncela (2018) explains that these themes do not only reflect what the protagonist endures, but also what the Mexican society faced in that time.

The film constructs a negative criticism towards the government of President Felipe Calderón, due to the social repercussion and violence of the war against drug trafficking that occurred during the president's six-year term. Bringas (2010) addresses the violence portrayed in the film and states that:

The excessive violence used by Estrada, which might seem unnecessary, is a sign of the impudence with which things happen in real life. It is a wake-up call to the viewer, who may generate in him an awareness that things are happening that are no longer just gossip, jokes or front page newspaper articles; on the contrary, they are situations that go beyond simply hearing them mentioned "out there." The presence of explicit violence in some sequences is precisely the way the director uses to show what everyone knows. (p. 7)

From the above, it is evident that the intention of the director Luis Estrada was not that of hiding the reality Mexico, but to uncover the consequences of what the government framed as a war against organized crime. The wake-up call to the viewer Bringas (2010) highlights is constructed by the director Luis Estrada through visuals, songs, symbols, and mainly through the dialogues present in the scenes of the film.

As it was reported through the CDA of the film scene in this paper, the fact that inside the dialogue no elements stood out is a clear indicator of the accurate reflection of how people speak and the reality they face. The way Benny and Cochiloco speak in the dialogue analyzed was written to match normal everyday interaction between people. By means of Mexican slang, idiomatic expressions, Spanish variations of language, Anglicisms, and even the recreation of the recognizable northern sound $\left[\int\right](<\mathrm{sh}>)$ the audience who watch the film can relate to it since the community discourse is correctly portrayed. By incorporating all these elements, the dialogue's naturality is successfully portrayed. Through this naturality, the allusion to reality is achieved in the film. This signals not only that the script was well written by Luis Estrada, but it also reflects the current depiction of Mexico, particularly of the North.

Furthermore, the popularity of this film and the fact that the government tried to stop its release in 2010 is also a clear indicator of the state of narco in Mexican society. Fernández Poncela (2018) reports the film was watched by more than two million spectators and raised around eighty-two millions of pesos. The author also highlights that "despite being rated C (only adults) the film positioned itself as the most successful from the films created within the celebrations of the bicentennial" (p. 3). Nevertheless, the government perceived this film as explicit criticism of Felipe Calderon's government due to the explicit references made through the film. From this, it could be inferred that narco and all that it encompasses is in the process of being accepted by the Mexican society and its discourse but the government probably will never recognize it as such, at least not in a formal way.

\section{Conclusion}

As previously discussed, one of the aims of CDA is to uncover any hidden message behind discourse in order to make transparent any opaque intention. Thus, it was surprising how the scene under analysis was the opposite of opaque, it was genuinely transparent. This means that the director Luis Estrada through the implementation of visuals, songs, symbols, and representative discourse made a real emphasis and reflection on the current Mexican social reality 
regarding drug trafficking and aspects such as migration, poverty, crime, and political corruption. This transparency appears to be the reason why the government tried to revoke its launch back in 2010 and perhaps why the Mexican audience seems to identify with what the film portrays. Therefore, although CDA's main objective is to shed light on the opaque intentions of discourse, this CDA has also enabled the highlight of discourse as a clear reflection of society in which narco has become a common topic in ordinary speech.

\section{Acknowledgements}

I would like to thank my professor Dr. Troy Crawford from the University of Guanajuato and my classmate Diana Francisco Ortega for their advice and feedback to develop my first critical discourse analysis. I would also like to thank CONACyT for funding my graduate degree.

This research did not receive any specific grant from funding agencies in the public commercial, or not-for-profit sectors.

The author declares no competing interests.

\section{References}

Blommaert, J., \& Bulcaen, C. (2000). Critical discourse analysis. Annual Review of Anthropology, 29, 447466. https://www.jstor.org/stable/223428

Bringas, C. (2010, October). El infierno. El espectador imaginario.

http://www.elespectadorimaginario.com/pages/octubre-2010/criticas/el-infierno.php.

Cabañas, M. A. (2014). Imagined narcoscapes: Narcoculture and the politics of representation. Latin American Perspectives, 41(2), 3-17. https://www.jstor.org/stable/24575495.

Campbell, H. 2014. Narco-propaganda in the Mexican "drug war": An anthropological perspective. Latin American Perspectives, 41(195). 60-77. https://www.jstor.org/stable/24575498.

Castellanos, B. (2011). Becoming chingón/a. In G. K. Hong\& R. A. Ferguson (Eds.), Strange affinities: The gender and sexual politics of comparative rationalization (pp. 270-292). Duke University Press.

Chouliaraki L., \& Fairclough, N. (1999). Discourse in late modernity: Rethinking Critical Discourse Analysis. University Press.

Coffin, C. (2006). English grammar in context. Book 3: Getting practical. The Open University.

Estrada, L. (Director) (2010). El infierno [Film]. Bandidos Films.

Fairclough, N. (1992). Discourse and social change. Polity.

Fairclough, N. (2001). Language and power ( $2^{\text {nd }}$ Ed.). Longman.

Fernández Poncela, A. M. (2018). El infierno ¿̇horror en los medios o realidad social? Revista Caribeña de Ciencias Sociales, 1, 1-12. https://www.eumed.net/rev/caribe/2018/o1/infierno-horror.html.

Fuentes Kraffczyk, F. O. (2019). Apuntes para una poética de la narcoliteratura. Universidad de Guanajuato.

http://repositorio.ugto.mx/bitstream/20.500.12059/1375/1/LISTO\%2002 00Po\%C3\%AgtN arcolitFinal20190919.pdf

Gomez, Mayorga, J., \& García Rangel, I. (2013). El infierno: Análisis estético de la identidad violentada. In M. C. Ríos Espinosa (Ed.), Sentidos y sensibilidades contemporáneas (pp. 1-27). Asociación Mexicana de Estudios de Estética. https://www.academia.edu/7675895/El infierno an\%C3\%A1lisis est\%C3\%Agtico de la i dentidad violentada. 
Haddu, M. (2016). Luis Estada: El Infierno (2010). In C. Wehr (Ed.), Clásicos del cine mexicano (pp. 627646). Iberoamericana Vervuert. https://doi.org/10.31819/9783954878543-032

Haidar, J., \& Herrera, E. C. (2018). Narcoculture? Narco-trafficking as a semiosphere of anticulture. Semiótica, 2018(222), 133-162. https://doi.org/10.1515/sem-2016-0151

Halliday, M. A. K. (1971). Linguistic function and literary style: An inquiry into the language of William Golding's The Inheritors. In S. Chatman (Ed.), Literary style: A symposium (pp. 330-368). Oxford University Press.

Halliday, M. A. K. (1978). Language as social semiotic. Arnold.

Haratyan, F. (2011). Halliday's SFL and social meaning. IPEDR, (17), 260-264. http://www.ipedr.com/vol17/49-CHHSS\%202011-H10074.pdf.

Jakobson, R. (1960). Concluding statement: Linguistics and poetics. In T. A. Sebeok (Ed.), Style in Language (pp. 350-377). Wiley.

O' Halloran, K. A. (2006). English context, book 2: Getting inside English grammar. The Open University.

Orpin, D. (2005). Corpus linguistics and critical discourse analysis: Examining the ideology of sleaze. International Journal of Corpus Linguistics, 10(1), 37-61. https://doi.org/10.1075/ijcl.10.1.03orp

Marez, C. (2004). Drug wars: The political economy of narcotics. University of Minnesota.

Michael, J. (2013). Narco-violencia y literatura en México. Sociologias, 15(34), 44-75. https://www.scielo.br/pdf/soc/v15n34/03.pdf.

Pérez Bernal, A. (2012). El infierno de Luis Estrada: Una mirada desde el esquizoanálisis de Gilles Deleuze. Cultura y Representaciones sociales, 6(12), 283-261. http://www.scielo.org.mx/scielo.php?script=sci arttext\&pid=S2007$81102012000100008 \& \ln g=$ es\&tlng=es.

Romo Linares, R. (2018). Los mirreyes de outlet: A critical discourse analysis on a broadcast portraying the postmodern lifestyle of Mexican Middle class. Open Journal for Studies in Linguistics, 1(2), 47-56. https://doi.org/10.32591/coas.ojsl.0102.03047m

Sharififar, M., \& Rahimi, E. (2015). Critical discourse analysis of political speeches: A case study of Obama's and Rouhani's speeches at UN. Theory and Practice in Language Studies, 5(2), 343-349. https://doi.org/10.17507/tpls.0502.14

Sibila, D. A., \& Weiss, A. J. (2014). Narco culture. In J. Mitchell Miller (Ed.), The encyclopedia of theoretical criminology (1 $1^{\text {st }}$ Ed., pp. 1-4). Blackwell Publishing Ltd. https://doi.org/10.1002/9781118517390.wbetc195

Wang, J. (2010). A critical discourse analysis of Barack Obama's speeches. Journal of Language Teaching and Research, 1(3), 254-261. https://doi.org/10.4304/jltr.1.3.254-261

Wodak, R. (1995). Critical linguistics and critical discourse analysis. In J. Zienkowsky, J. Östman \& J. Verschueren (Eds.), Discursive pragmatics (pp. 204-210). John Benjamins Publishing Company. https://doi.org/10.1075/hoph.8.04wod

Wodak, R. (1997). Critical discourse analysis and the study of doctor-patient interaction. In B. L. Gunnarsson, P. Linell \& B. Nordberg (Eds.), The Construction of Professional Discourse (pp. 173-200). Longman.

Zhuanglin, H. (1988). A course of linguistics. Peking University Press. 